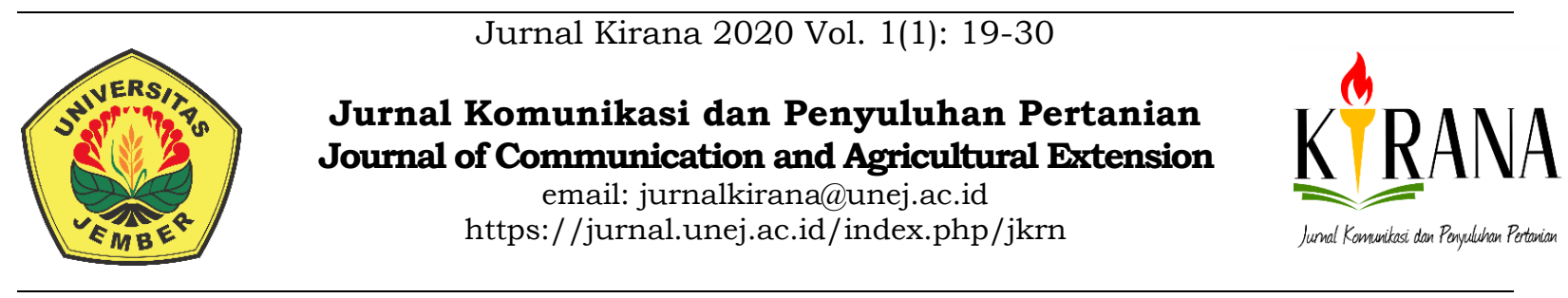

\title{
Proses Perubahan Sosial Pengembangan Wisata Pesisir Payangan di Desa Sumberejo Kecamatan Ambulu Kabupaten Jember
}

\section{The Process Of Social Change Towards The Development Of Payangan Beach Tourism At Sumberrejo Village, Ambulu District Jember Regency}

\section{Indah Tri Qurniawati1 ${ }^{\bowtie}$ dan Diah Puspaningrum²}

${ }^{1}$ Program Studi Agribisnis Fakultas Pertanian Universitas Jember

2 Program Studi Penyuluhan Pertanian Fakultas Pertanian Universitas Jember

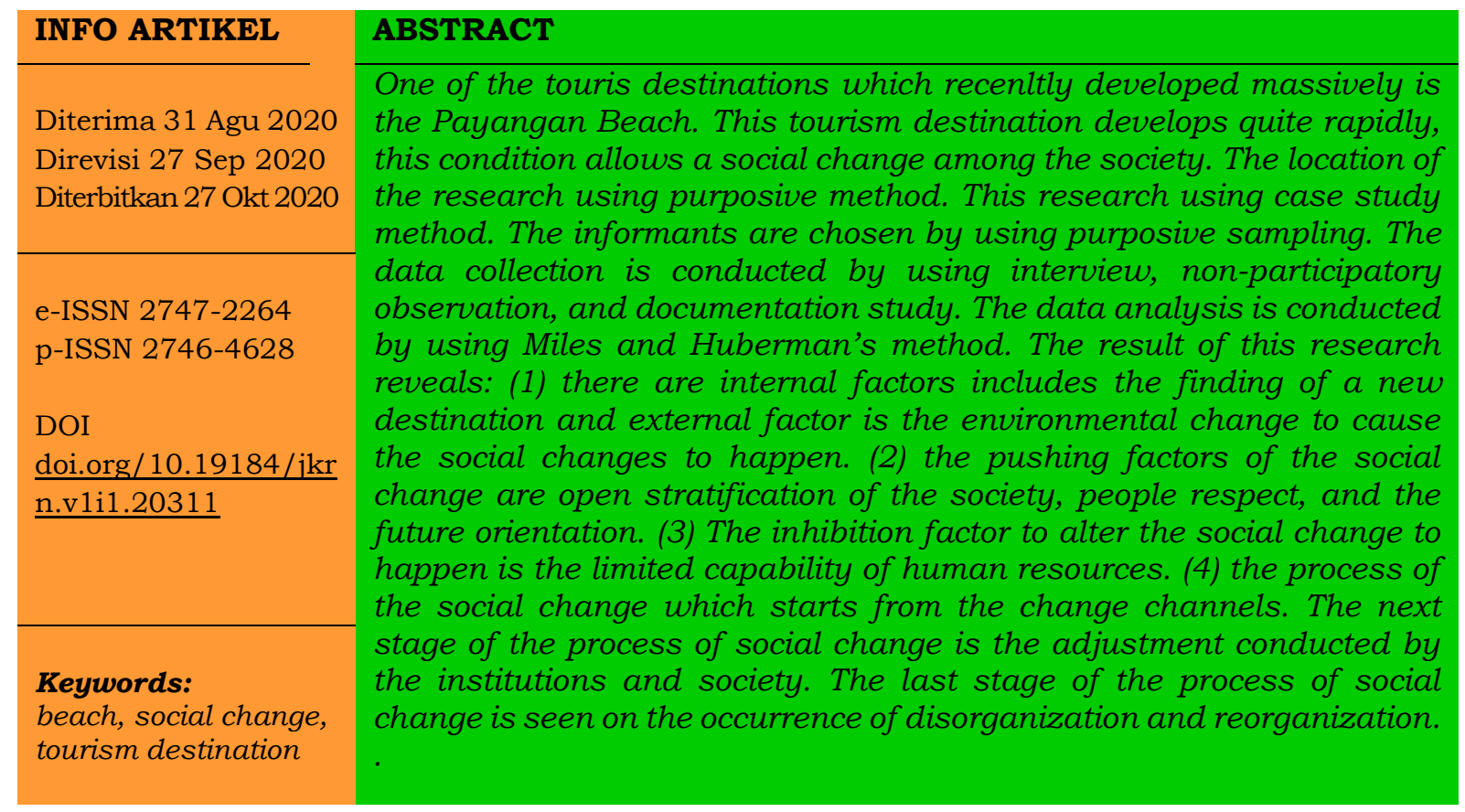

$凶$ Penulis Koresponden :

E-mail : indahtriq@gmail.com 


ABSTRAK
Salah satu destinasi wisata yang belakangan berkembang pesat
adalah Pantai Payangan. Destinasi wisata ini berkembang cukup
pesat, kondisi ini memungkinkan terjadinya perubahan sosial di
masyarakat. Lokasi penelitian menggunakan metode purposive.
Penelitian ini menggunakan metode studi kasus. Informan dipilih
dengan menggunakan purposive sampling. Pengumpulan data
dilakukan dengan wawancara, observasi non partisipatif, dan studi
dokumentasi. Analisis data dilakukan dengan metode Miles dan
Huberman. Hasil penelitian ini mengungkapkan: (1) terdapat faktor
internal yang meliputi penemuan destinasi baru dan faktor eksternal
yaitu perubahan lingkungan yang menyebabkan terjadinya
perubahan sosial. (2) Faktor pendorong perubahan sosial adalah
stratifikasi masyarakat yang terbuka, rasa hormat masyarakat, dan
orientasi masa depan. (3) Faktor penghambat untuk mengubah
terjadinya perubahan sosial adalah keterbatasan kemampuan
sumber daya manusia. (4) proses perubahan sosial yang dimulai dari
saluran perubahan. Tahapan selanjutnya dari proses perubahan
sosial adalah penyesuaian yang dilakukan oleh lembaga dan
masyarakat. Tahap terakhir dari proses perubahan sosial terlihat
pada terjadinya disorganisasi dan reorganisasi..
Kata kunci:
pantai, perubahan
sosial, tujuan wisata

\section{PENDAHULUAN}

Wilayah Pesisir memiliki sumberdaya yang sangat potensial untuk dikembangkan. Pengembangan wilayah pesisir bisa dari lingkungan yang berbeda. Menurut Effendy (2009), pengembangan wilayah pesisir bisa dari lingkungan yang bersifat alami dan juga bisa dari lingkungan yang bersifat buatan. Salah satu upaya pengembangan wilayah pesisir yang sangat potensial yaitu dari sektor pariwisata.

Devy (2017) menjelaskan pariwisata sebagai suatu keseluruhan elemenelemen terkait yang didalamnya terdiri dari wisatawan, daerah tujuan wisata, perjalanan, industri yang merupakan kegiatan pariwisata. Pengertian pariwisata berbeda dengan wisata. Sari (2015) menjelaskan wisata sebagai tujuan bagi seseorang untuk mengunjungi sesuatu yang mempunyai daya tarik baik berupa tempat, benda atau alam yang bertujuan memberikan rekreasi bagi diri seseorang.

Kontribusi sektor pariwisata bagi perekonomian Indonesia cukup signifikan. Menurut Kementerian Pariwisata (2016), dampak kepariwisataan terhadap Produk Domestik Bruto (PDB) tahun 2016 sebesar 4,03\% dari PDB nasional. Sektor pariwisata juga memiliki peran strategis dalam menciptakan nilai tambah dan menyerap banyak tenaga kerja.

Pada awal tahun 2017 telah terjalin kerja sama antara kementerian pariwisata dan kementerian kelautan dan perikanan untuk mengembangkan sektor kepariwisataan bahari nasional termasuk wisata Pesisir. menurut Effendy (2009) peranan sumberdaya pesisir diperkirakan akan semakin meningkat dimasa-masa mendatang dalam menunjang pembangunan ekonomi nasional, regional, maupun lokal. 
Kabupaten jember memiliki tempat wisata yang melimpah baik di dataran tinggi maupun di dataran rendah. Salah satu tempat wisata yang paling banyak di kunjungi oleh wisatawan yakni wisata Pantai Payangan yang terletak di Desa Sumberejo Kecamatan Ambulu. Wisata ini mengalami kemajuan yang sangat pesat pada tahun 2015 karena adanya upaya pengembangan yang dilakukan oleh masyarakat setempat. Pengembangan wisata dilakukan dengan dibukanya wisata Bukit Samboja dan Bukit Suroyo atau yang kini dikenal dengan nama Teluk Love. Pengembangan wisata juga dilakukan dengan membuka wahana wisata river tubing di muara sungai Pesisir Payangan.

Sejak wisata Pesisir Payangan berkembang, masyarakat setempat terus mengalami perubahan. Lingkungan masyarakat yang dulu sepi sekarang tampak sangat padat karena banyak masyarakat yang membuka usaha seperti warung makan dan tempat penitipan kendaraan. Perubahan tersebut kemudian membawa pengaruh pada kondisi sosial dan ekonomi masyarakat.

Tujuan penelitian ini (1) untuk mengetahui faktor penyebab terjadinya perubahan sosial pengembangan wisata Pesisir Payangan. (2) untuk mengetahui faktor pendorong terjadinya perubahan sosial pengembangan wisata Pesisir Payangan. (3) untuk mengetahui faktor penghambat terjadinya perubahan sosial pengembangan wisata Pesisir Payangan. (4) untuk mengetahui proses perubahan sosial pengembangan wisata Pesisir Payangan di Desa Sumberejo Kecamatan Ambulu Kabupaten Jember.

\section{METODE PENELITIAN}

Metode penentuan daerah penelitian dilakukan secara sengaja purposive method dengan pertimbangan bahwa wilayah Pesisir Payangan merupakan suatu wilayah yang mengalami perkembangan wisata yang sangat pesat. Metode penelitian yang digunakan yaitu studi kasus. Metode penentuan informan dilakukan secara purposive sampling dengan kriteria tertentu. Pengumpulan data dilakukan dengan menggunakan metode wawancara semiterstruktur, observasi non partisipan dan studi dokumentasi. Metode analisis data yang digunakan yaitu analisis Miles dan Huberman. Langkah langah dalam analisis data Miles dan Huberman yaitu

1. Data Reduction (Reduksi data)

Mereduksi data berati merangkum, memilih hal-hal yang pokok, memfokuskan pada hal-hal yang penting, dicari tema dan polanya. Reduksi data dilakukan dengan memfokuskan data hasil wawancara, observasi dan dokumentasi ke dalam kelompok-kelompok sesuai dengan rumusan masalah.

2. Data Display (Penyajian Data)

Setelah data direduksi, maka langkah selanjutnya adalah penyajian data. Penyajian data bisa dilakukan dalam bentuk uraian singkat, bagan, hubungan antar kategori, flowchart, dan sejenisnya.

3. Conclusion Drawing/Verification (Penarikan kesimpulan/Verifikasi) Kesimpulan awal yang disampaikan masih bersifat sementara sebab dalam penelitian kualitatif akan selalu mengalami perubahan sampai data menjadi jenuh, dan akan berubah bila tidak ditemukan bukti-bukti yang kuat dan mendukung pada tahap pengumpulan data berikutnya. Apabila kesimpulan yang dikemukakan pada tahap awal didukung oleh bukti-bukti yang valid dan konsisten saat peneliti 
kembali ke lapangan mengumpulkan data, maka kesimpulan yang dikemukakan merupakan kesimpulan yang kredibel. Uji keabsahan data pada penelitian ini dilakukan dengan menggunakan triangulasi teknik dan triangulasi sumber.

\section{HASIL DAN PEMBAHASAN}

\section{Faktor Penyebab Perubahan Sosial Pengembangan Wisata Pesisir Payangan di Desa Sumberejo Kecamatan Ambulu Kabupaten Jember}

Perubahan sosial yang terjadi pada masyarakat Pesisir Payangan dilihat dengan membandingkan keadaan dari sebelum dilakukan pengembangan wisata dengan kondisi setelah dilakukan pengembangan wisata. Berdasarkan hasil penelitian yang telah dilakukan, didapatkan hasil mengenai faktor-faktor pada perubahan sosial sebagai berikut.

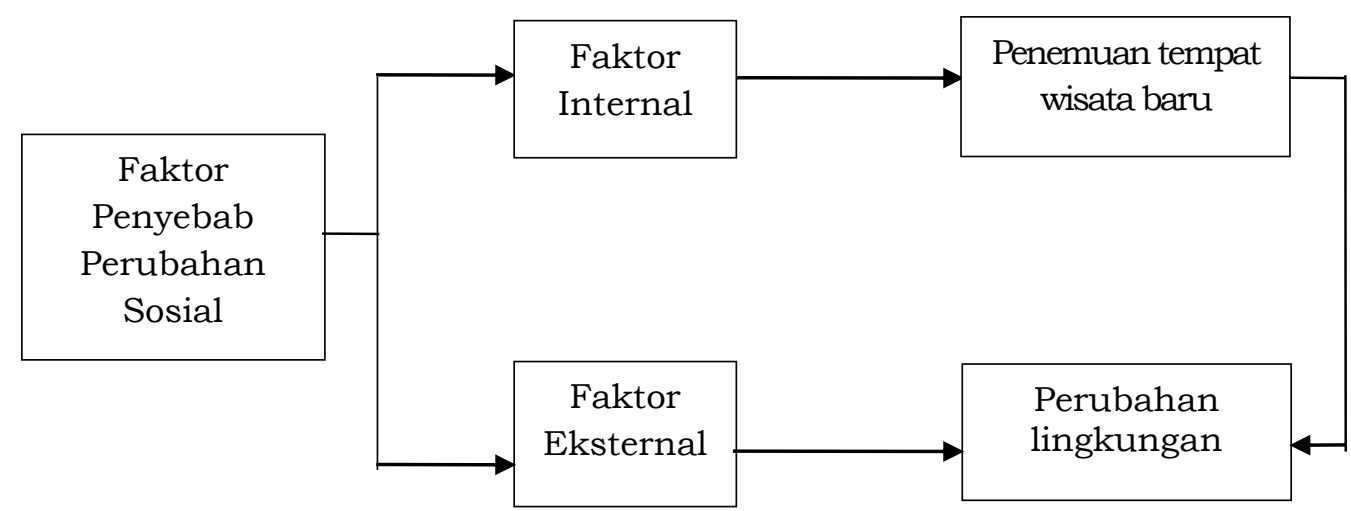

Gambar 1. Faktor Penyebab Perubahan Sosial di Pesisir Payangan

Berdasarkan gambar tersebut dapat diketahui alur faktor penyebab perubahan sosial. Perubahan sosial yang terjadi di Pesisir Payangan disebabkan oleh faktor dari dalam masyarakat (internal) dan faktor dari luar masyarakat (eksternal). a. Faktor Internal: Penemuan tempat wisata baru

Penemuan tempat wisata baru yang dimaksud yakni wisata yang kini dikenal dengan nama Teluk Love. Dikatakan penemuan baru bukan karena sebelumnya tidak ada, tetapi keberadaannya baru ditemukan dan baru disadari serta dikelola menjadi suatu tempat wisata. Penemuan wisata baru menjadi faktor penyebab perubahan sosial dimaksudkan bahwa sejak ditemukannya Teluk Love, wisata ini menjadi semakin terkenal dan pengunjung semakin banyak, sehingga masyarakat mengalami perubahan. Perubahan yang paling tampak dari adanya penemuan baru yakni masyarakat banyak yang membuka usaha, sehingga lingkungan yang awalnya sepi tampak semakin padat.

b. Faktor Eksternal: Perubahan lingkungan

Berdasarkan Gambar 1 terlihat bahwa penemuan tempat wisata baru memberikan pengaruh pada perubahan lingkungan fisik. Perubahan lingkungan yang terlihat dengan semakin banyaknya warung-warung dan tempat penitipan kendaraan yang semakin banyak memberikan perubahan pada aspek sosial dan ekonomi. Pada aspek sosial dengan semakin banyak yang mendirikan usaha menimbulkan persaingan bagi masyarakat yang memiliki usaha tersebut. Mereka saling berlomba untuk mendapat pelanggan. Perubahan lingkungan menyebabkan terjadinya perubahan pada 
struktur sosial masyarakat yang mana masyarakat membentuk kelompok-kelompok sesuai dengan wilayah kerjanya. Hampir disetiap penitipan kendaraan memiliki personil sejumlah 2 orang atau lebih. Selain pada aspek sosial, perubahan lingkungan juga menyebabkan terjadinya perubahan pada aspek ekonomi. Semakin banyak masyarakat yang mendirikan usaha baik berupa tempat penitipan kendaraan, warung makan, tempat kamar mandi umum, ojek perahu maupun menjadi guide menmbah pendapatan masyarakat setempat. Hal ini berarti telah terjadi perubahan struktur mata pencaharian. Awalnya masyarakat hanya bekerja sebagai nelayan, sekarang banyak yang membuka usaha. Artinya, sumber penghasilan keluarga tidak hanya mengandalkan dari hasil laut tetapi juga ada tambahan dari hasil usaha. Selain itu, perubahan yang terjadi juga mengurangi pengangguran.

\section{Faktor pendorong Perubahan Sosial Pengembangan Wisata Pesisir Payangan di Desa Sumberejo}

Faktor pendorong dijelaskan sebagai faktor-faktor yang dapat mempercepat atau memperlancar proses perubahan sosial. Hasil ini dapat dilihat pada gambar berikut

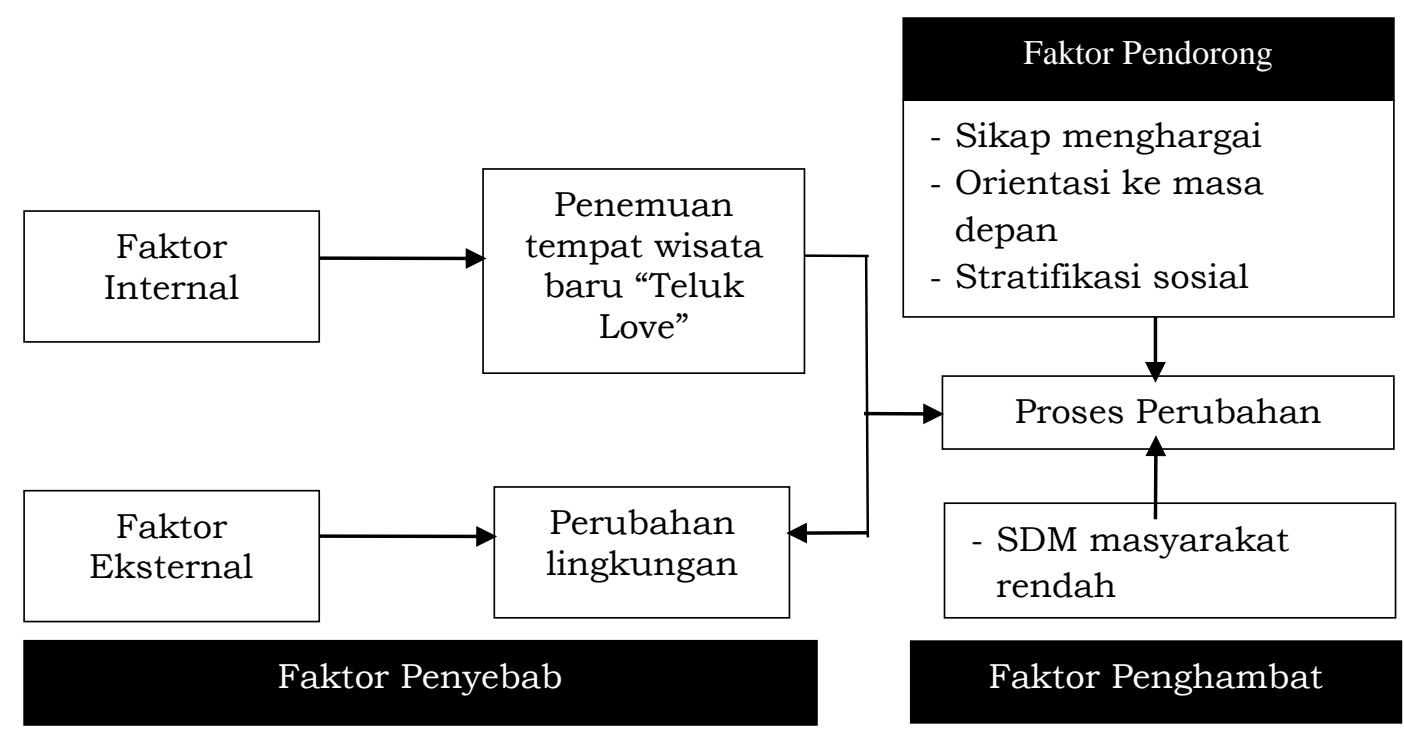

Gambar 2. Alur Faktor Penyebab, Faktor Pendorong dan Faktor Penghambat Perubahan Sosial

1. Sikap masyarakat yang menghargai

Sikap masyarakat yang demikian dapat dilihat dari sikap masyarakat dalam menanggapi sesuatu yang baru. Masyarakat melihat, selama sesuatu tersebut memberikan dampak yang positif maka masyarakat akan mengapresiasi dengan mengakui dan meniru apa yang dianggap baik. Sikap yang demikian bukan berarti masyarakat tidak menghargai karena ikut-ikutan, tetapi karena masyarakat menghargai apa yang baru dan menganggap bahwa itu menguntungkan sehingga masyarakat meniru dan menerapkannya. Hal ini menjadi salah satu karakteristik dari masyarakat Pesisir Payangan bahwa dalam bertindak khususnya terkait dengan kegiatan wisata ini harus ada yang memberi contoh atau yang mengawali. 
Sikap masyarakat yang menghargai adanya seseorang yang berprestasi atau berhasil ditunjukkan dengan rasa hormat yang diberikan kepada orang tersebut. Masyarakat menganggap bahwa orang yang berprestasi tersebut telah berjasa untuk masyarakat sehingga mereka saat ini lebih bisa menghargai. Apabila masyarakat mampu menunjukkan sikap menghargai baik terhadap seseorang yang berprestasi maupun seseorang yang menemukan sesuatu yang baru maka hal ini dapat mendorong masyarakat untuk selalu berprestasi melalui berbagai penemuanpenemuan baru lewat hasil karya mereka yang diharapkan dapat membawa perubahan dan kebaikan dalam kehidupan masyarakatnya.

2. Orientasi ke masa depan

Masyarakat dalam bertindak khususnya mereka sebagai pelaku wisata sudah berorientasi ke depan. Dalam artian tindakan yang diambil tidak hanya berfikir untuk manfaat yang diperoleh hari ini tetapi juga bagaimana resiko yang akan dihadapi di depan dengan menyiapkan solusinya, serta meyiapkan perencanaan ke depan dengan matang. Orientasi ke depan ini seperti perencanaan untuk mengembangkan wisata dengan membuat flying fox dan kolam renang pantai di sebelah timur Bukit Suroyo, meskipun sampai saat ini masih belum ada upaya lebih lanjut. Pengembangan juga dilakukan oleh Kelompok nelayan KUB Lumba-Lumba dengan mengembangkan wahana wisata river tubing dan banana boat.

Sikap masyarakat yang sudah berorientasi ke depan merupakan suatu bentuk faktor yang akan mendorong terjadinya perubahan sosial seperti yang disampaikan oleh Djazifah (2011) bahwa masyarakat yang mampu berfikir ke arah masa depan (memiliki visi, misi dan tujuan hidup yang jelas) akan terdorong untuk mewujudkan cita-cita masa depannya, sehingga tumbuh sebagai masyarakat yang dinamis, kreatif, yaitu masyarakat yang selalu berusaha menghasilkan penemuan-penemuan baru yang akan merubah kehidupan masyarakatnya menuju terwujudnya masyarakat yang dicitacitakan.

3. Stratifikasi sosial masyarakat yang terbuka

Berdasar penelitian diperoleh hasil bahwa stratifikasi sosial masyarakat Pesisir Payangan bersifat terbuka. Maksudnya bahwa setiap anggota masyarakat mempunyai kesempatan yang sama melalui usaha-usahanya untuk bisa naik ke lapisan yang lebih tinggi dan sebaliknya bahwa masyarakat juga bisa turun dari lapisan yang tinggi ke lapisan yang lebih rendah. Hal ini terlihat dari bagaimana Bapak Suto sebagai pengelola Teluk Love yang dulunya tidak dihormati bahkan dikucilkan oleh masyarakat sebab lebih memilih untuk tinggal di Bukit Suroyo, setelah keberhasilannya mengelola Teluk Love kini menjadi lebih dihormati oleh masyarakat dan dipandang sebagai seseorang yang memiliki kedudukan tinggi.

Hal ini sesuai dengan hasil penelitian Mulyadi (2015) bahwa adanya sistem yang terbuka di dalam lapisan masyarakat akan menimbulkan gerak sosial vertikal yang luas atau berarti memberi kesempatan kepada para individu untuk maju atas dasar kemampuan sendiri. Hal tersebut bisa memacu individu dalam masyarakat untuk berprestasi dengan memberikan ide, gagasan ataupun hal lainnya untuk kemajuan masyarakat yang bisa mendorong terjadinya perubahan sosial dimasyarakat. 


\section{Faktor penghambat Perubahan Sosial Pengembangan Wisata Pesisir Payangan di Desa Sumberejo}

Pada penelitian yang dilakukan didapatkan hasil bahwa yang menjadi faktor penghambat perubahan sosial dengan adanya wisata Pesisir Payangan di Desa Sumberejo yakni terkait Sumber Daya Masyarakat (SDM) yang mayoritas masih tergolong rendah. SDM yang rendah ditunjukkan dengan tingkat pendidikan masyarakat yang mayoritas lulusan Sekolah Dasar (SD). Data mengenai tingkat pendidikan masyarakat dapat dilihat pada Tabel 1 berikut.

Tabel 1. Data tingkat Pendidikan Masyarakat Dusun Watu Ulo

\begin{tabular}{rlrc}
\hline No & \multicolumn{1}{c}{ Tingkat Pendidikan } & Jumlah (Jiwa) & Persentase (\%) \\
\hline 1 & Tidak/Belum Sekolah & 87 & 15,45 \\
2 & Tidak Tamat SD/Sederajat & 147 & 26,11 \\
3 & Tamat SD/Sederajat & 95 & 16,87 \\
4 & SLTP/ Sederajat & 72 & 12,78 \\
5 & SLTA/ Sederajat & 129 & 22,91 \\
6 & Diploma IV/Strata I & 13 & 2,30 \\
7 & Diploma I/II & 12 & 2,13 \\
8 & Akademi/Diploma III/S. Muda & 8 & 1,42 \\
\hline \multicolumn{2}{r}{ Jumlah } & $\mathbf{5 6 3}$ & $\mathbf{1 0 0}$ \\
\hline
\end{tabular}

Sumber : Data Penduduk Desa Sumberejo 2017

Berdasarkan data sekunder yang diperoleh dari profil desa Sumberejo diketahui bahwa mayoritas tingkat pendidikan masyarakat Dusun Watu Ulo hanya sampai pada tingkat Sekolah Dasar (SD) dengan jumlah yaitu sebesar 42,98\%. Rendahnya tingkat pendidikan menjadikan masyarakat cenderung kurang berinisiatif dan lebih bergantung pada orang lain. Mereka cenderung mengandalkan orang lain dalam bertindak kaitannya dengan pengembangan wisata. Mereka tidak bertindak sebagai seseorang yang memiliki inisiatif sendiri untuk berkarya ataupun berubah agar lebih baik, tetapi hanya menunggu hasil orang lain.

Hasil tersebut sesuai dengan yang disampaikan oleh Martono (2014) bahwa masyarakat yang memiliki sistem pendidikan yang maju tentu saja dapat mempercepat perubahan sosial dalam masyarakat tersebut, dan sebaliknya masyarakat yang memiliki sistem pendidikan yang kurang maju dapat memperlambat perubahan sosial dalam masyarakat.

Proses Perubahan Sosial Pengembangan Wisata Pesisir Payangan di Desa Sumberejo

Proses terjadinya perubahan sosial ada 3 tahap yaitu penyesuaian masyarakat terhadap perubahan, saluran-saluran perubahan sosial serta Disorganisasi dan Re-organisasi. Uraian mengenai proses terjadinya perubahan sosial dapat dilihat pada Gambar 1.3.

1) Saluran perubahan sosial

Saluran perubahan sosial merupakan saluran-saluran yang dilalui oleh suatu proses perubahan. Berdasarkan gambar 3 diketahui saluran perubahan sosial yaitu berawal dari 3 lembaga utama.

(1) Lembaga pemerintah desa kepada pengelola wisata Bukit Samboja 
Awalnya pemerintah desa menyampaikan gagasannya kepada juru kunci Bukit Samboja agar menjadikan Bukit Samboja bagian dari wisata, sehingga muncul ide untuk membuat bukit ini menjadi wisata. Pengelola Bukit Samboja juga bekerja sama dengan lembaga lain yang juga turut mendukung pengembangan wisata Bukit Samboja. Lembaga tersebut yakni dari lembaga pariwisata yaitu Jember Ecotourism, Asosiasi Desa Wisata (ASIDEWI), Pesona Indonesia dan Kelompok Sadar Wisata (Pokdarwis). Lembaga tersebut berperan sebagai lembaga pendukung dalam upaya pengembangan wisata bukit samboja.

Saluran Perubahan Sosial
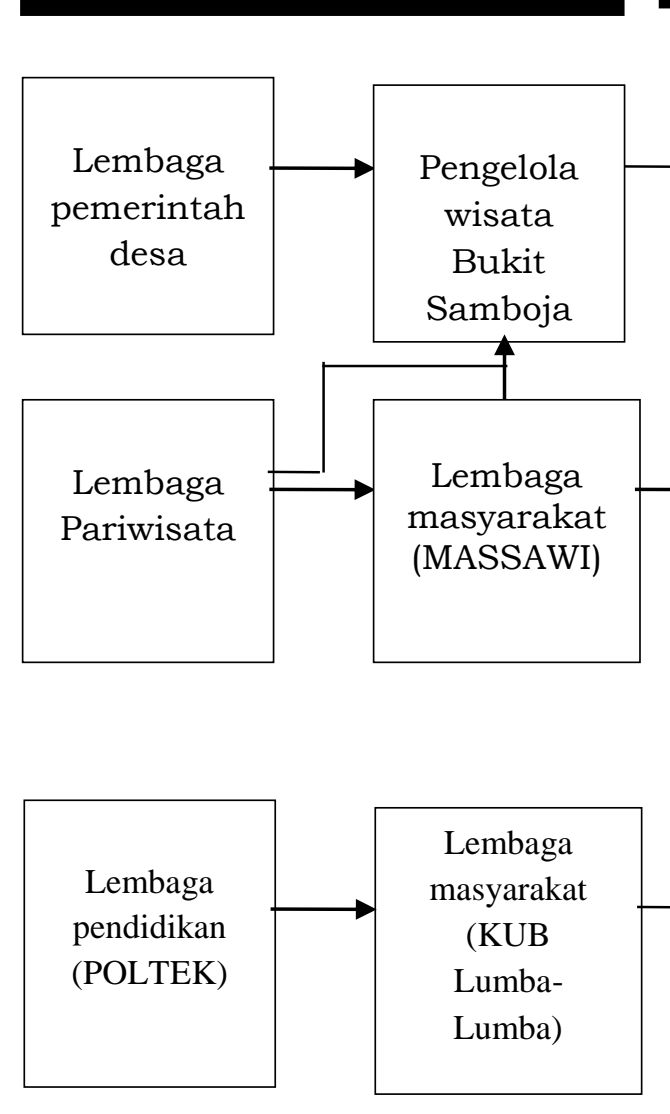

Saluran Perubahan Sosial
Penyesuaian diri lembaga

Disorganisasi

$(+)$

Sadar wisata

\section{$(-)$}

Menurunnya

tingkat

reliciuce

$(+)$

- Sadar wisata

- Produktif

\section{$(-)$}

- Maraknya perubuatan menyimpang

- Materialistis

- Konsumtif

Reorganisasi

\section{Gambar 3. Alur Proses Perubahan Sosial}

(2) Lembaga pariwisata kepada pengelola wisata Teluk Love

Saluran perubahan sosial yang kedua yaitu dari lembaga pariwisata kepada pengelola wisata Teluk Love. Gagasan untuk mengembangkan wisata muncul ketika Ketua Kelompok MASSAWI yaitu Bapak Suto mengikuti pelatihan-pelatihan dari lembaga pariwisata ASIDEWI. Setelah mengikuti pelatihan tersebut muncullah ide untuk mengembangkan wisata daerahnya karena daerahnya memiliki potensi yang sangat bagus untuk dikembangkan. Sehingga dilakukan upaya pengembangan yang kemudian ditemukannya Teluk Love 
(3) Lembaga pendidikan Politeknik Negeri Jember (POLTEK) kepada kelompok nelayan KUB Lumba-lumba

Saluran perubahan yang ketiga dari lembaga pendidikan POLTEK (Politeknik Negeri Jember) kepada KUB Lumba-lumba. Pada tahun 2016 mahasiswa BEM POLTEK memberikan pelatihan kepada KUB Lumba-lumba terkait wisata river tubing yang dilakukan dengan menarik ban-ban yang sudah diberi tali pengait dan ditarik menggunakan perahu nelayan di muara sungai Pesisir Payangan. Upaya ini terus dikembangkan sampai sekarang KUB Lumba-lumba mengembangkan wahana wisata banana boat.

2) Penyesuaian masyarakat terhadap perubahan

(a) Penyesuaian diri lembaga

Penyesuaian atau adaptasi

Menurut Nurisnaeny (2016) pada saat kelompok manusia mulai melakukan proses adaptasi dengan lingkungannya, maka terbentuk hubungan yang saling mempengaruhi antara manusia dengan lingkungannya. Upaya penyesuaian yang dilakukan oleh lembaga sosial masyarakat sejak terjadinya perubahan salah satunya yaitu munculya lembaga baru dalam masyarakat. Lembaga baru tersebut merupakan lembaga sosial yang bergerak dibidang pariwisata. Lembaga tersebut bernama APJINDO (Asosiasi Pariwisata Payangan Jember Indonesia) dan POKDARLING (Kelompok Sadar Lingkungan). Lembaga ini berdiri sejak wisata Pesisir Payangan mengalami kemajuan. Hal ini sesuai dengan hasil penelitian Pratama (2013) bahwa semakin berkembangnya pariwisata membuat semakin bertambahnya jumlah wisatawan yang datang. Keberadaan wisatawan jelas membutuhkan suatu jasa yang dapat menyediakan segala kebutuhan yang diperlukan. Keadaan tersebut yang kemudian melatarbelakangi tumbuhnya organisasi-organisasi sosial yang mampu menyediakan kebutuhan wisatawan dalam bidang jasa.

Kelompok Usaha Bersama (KUB) juga menyesuaikan diri dengan cara turut serta dalam kegiatan pariwisata. KUB Baruna Jaya awalnya hanya sebagai lembaga yang bergerak pada wilayah perikanan saja sekarang terjun dalam bidang pariwisata dengan membuka lahan penitipan kendaraan yang dijaga oleh anggota kelompoknya. Lembaga sosial lain yang bergerak khusus dibidang pariwisata juga melakukan penyesuaian dengan cara yang lain. Lembaga tersebut yaitu MASSAWI (Masyarakat Sadar Wisata) yang melakukan penyesuaian dengan cara memperbanyak sharing dengan lembaga lain diluar daerah yang bergerak pada bidang yang sama.

(b) Penyesuaian diri individu dalam masyarakat

Masyarakat sudah mulai sadar akan wisata. Sikap ini ditunjukkan oleh masyarakat dengan semakin meningkatnya kepedulian terhadap kebersihan lingkungan. Awalnya masyarakat sering membuang sampah sembarangan, kini sudah mulai membiasakan untuk menjaga kebersihan dengan membuang sampah pada tempatnya. Masyarakat juga semakin sadar untuk melakukan penghijauan. Kondisi Pesisir Payangan yang awalnya gersang kini semakin hijau.

Masyarakat juga menyesuaikan dengan membuka usaha seperti warungwarung makan tempat penitipan kendaraan, kamar mandi umum, membuka jasa tour guide dan jasa ojek perahu. Upaya penyesuaian yang dilakukan masyarakat 
dengan membuka usaha lain menunjukkan adanya mobilitas horizontal dalam masyarakat, yakni masyarakat nelayan mengalami perubahan pekerjaan. Penyesuaian yang dilakukan baik oleh lembaga maupun individu dalam masyarakat terjadi karena lingkungan yang berubah atau sebaliknya. Hal tersebut sesuai dengan teori yang disampaikan oleh Bennet dalam Helmi \& Satria (2012) bahwa tingkah laku manusia dapat mengubah suatu lingkungan atau sebaliknya, lingkungan yang berubah memerlukan suatu adaptasi yang selalu dapat diperbaharuhi agar manusia dapat bertahan dan melangsungkan kehidupan di lingkungan tempat tinggalnya.

3) Disorganisasi dan reorganisasi

(a) Disorganisasi

Disorganisasi merupakan suatu proses berpudarnya norma-norma dan nilai-nilai dalam masyarakat karena perubahan-perubahan yang terjadi pada lembaga-lembaga kemasyarakatan. perubahan sosial yang telah terjadi di Pesisir Payangan telah menimbulkan adanya disorganisasi yaitu lunturnya tradisi yang ada pada masyarakat. Disorganisasi yang terjadi pada hal positif dan negatif. Disorganisasi positif yang terjadi yaitu masyarakat menjadi lebih sadar wisata. Sikap masyarakat yang sadar wisata ini ditunjukkan dengan cara berpakaiannya yang awalnya berpakaian terbuka bagi kaum laki-laki atau biasa disebut ote-ote dan menggunakan sarung sekarang jadi lebih tertutup. Hal lain yang juga dianggap sudah mulai luntur yaitu terkait dengan tradisi masyarakat buang air besar di sembarang tempat. Dulu hal tersebut menjadi suatu kebiasaan di masyarakat bahwa membuang air besar di pasir-pasir pantai, di batu-batu karang kemudian dibiarkan. Menurut Sztrompka (2015) ada tradisi yang dipelihara bukan karena pilihan sadar tetapi karena kebiasaan semata. Dipertahankan bukan karena dihargai atau dipuja tetapi dinilai sebagai cara hidup yang tak menyusahkan. Sama dengan masyarakat Pesisir Payangan tersebut bahwa karena mereka dulunya banyak yang tidak mempunyai tempat buang air besar dan karena rumah mereka dekat dengan sungai sehingga kebiasaan buang air besar di pantai ini dianggap sebagai cara yang mudah dan tidak menyusahkan. Kebiasaan terebut saat ini sudah luntur. Kedua hal tersebut merupakan disorganisasi positif.

Disorganisasi negatif dalam hal ini berkaitan dengan kebiasaan masyarakat dalam beribadah. Awalnya masyarakat sering berjamaah di mushola jika sudah memasuki waktu sholat. Tetapi saat ini masyarakat yang datang dan berjamaah di mushola jadi sangat sedikit dan tidak sebanyak dulu. Hal ini terjadi karena masyarakat saat ini lebih mementingkan untuk mencari uang. Dulu jika mendengar adzan, masyarakat banyak yang berjamaah di mushola tetapi saat ini meskipun mendengar adzan masyarakat tetap melanjutkan pekerjaannya untuk menjaga tempat penitipan kendaraannya. Sebab terkadang pengunjung yang datang sampai larut malam.

(b) Reorganisasi

Reorganisasi merupakan suatu proses pembentukan norma-norma dan nilainilai baru agar serasi dengan lembaga-lembaga kemasyarakatan yang telah mengalami perubahan. Reorganisasi yang terjadi bernilai positif dan negatif. Reorganisasi positif yang terjadi yakni masyarakat menjadi lebih produktif. Produktif dalam hal ini ditunjukkan dengan munculnya kebiasaan masyarakat membuat sirup 
mangrove dan souvenir yang dapat dijual guna untuk menambah pendapatan. Hanya saja kebiasaan baru tersebut belum sepenuhnya dilaksanakan, hanya beberapa warga saja yang sudah mulai melakukan kebiasaan baru tersebut.

Reorganisasi positif lain yaitu munculnya kebiasaan baru para pelaku wisata terkait dengan kebiasaan berpakaian. Para pelaku wisata dalam hal ini penjaga tempat penitipan kendaraan yang awalnya tidak berseragam kini menjadi berseragam, dengan petugas yang menggunakan pakaian seragam tentu memudahkan wisatawan untuk mengenali mereka sebagai petugas parkir sehingga dapat meningkatkan pelayanan. Reorganisasi yang terjadi juga ada yang bernilai negatif. Hal ini menimbulkan keresahan bsetalah wisata ini mengalami perkembangan muncul keresahan di masyarakat bahwa daerahnya kini menjadi semakin marak perbuatan menyimpang seperti banyaknya pemuda yang minum minuman keras dan memicu perbuatan maksiat yang dilakukan dilokasi wisata.

Hal negatif yang juga muncul setelah wisata ini berkembang yaitu sifat masyarakat yang menjadi lebih materialistis. Masyarakat dalam kesehariannya saat ini menjadi lebih giat bekerja, yang dulu rajin ke mushola saat ini memiliki pandangan lain bahwa yang terpenting untuk saat ini kerja. Hal ini karena terkadang pengunjung juga datang pada malam hari atau bahkan menginap. Sehingga ada yang menjaga kendaraan pengunjung hingga larut malam. Hal ini yang kemudian menjadikan masyarakat menjadi lebih materialistis dengan memandang segala sesuatu secara profit oriented sehingga mereka memanfaatkan segala sesuatu yang ada untuk menghasilkan uang. Reorganisasi negatif juga munculnya sikap masyarakat yang cenderung konsumtif. Dengan semakin banyak masyarakat yang mendirikan usaha sehingga pendapatan mereka mengalami peningkatan. Peningkatan pendapatan masyarakat ini menjadikan daya beli masyarakat menjadi lebih meningkat. Hal ini ditunjukkan dengan konsumsi masyarakat terhadap makanan dan juga alat elektronik menjadi semakin meningkat.

Berdasarkan seluruh uraian yang dijelaskan maka perubahan sosial yang terjadi pada masyarakat Pesisir Payangan dapat digolongkan berdasarkan waktu terjadinya, berdasarkan dampak yang ditimbulkan serta berdasarkan proses terjadinya. (1) Menurut waktu terjadinya perubahan sosial yang terjadi di Pesisir Payangan termasuk dalam perubahan sosial cepat. Indikator tidak ada yang secara khusus menyebutkan berapa lama waktu untuk menentukan apakah suatu perubahan termasuk dalam perubahan cepat atau perubahan lambat, yang bisa dijadikan sebagai tolak ukur adalah bahwa perubahan sosial yang satu lebih cepat atau lebih lambat dari perubahan sosial yang lain. (2) Berdasar dampak yang ditimbulkan Perubahan sosial yang terjadi jika dilihat dari dampak yang ditimbulkan termasuk dalam perubahan besar. Perubahan kecil merupakan perubahan yang terjadi pada unsur-unsur struktur sosial yang tidak membawa pengaruh langsung atau berarti bagi masyarakat. Hal ini berarti perubahan yang berdampak besar merupakan perubahan yang memberikan perubahan pada aspek dasar kehidupan masyarakat seperti perubahan dalam lembaga masyarakat, stratifikasi masyarakat, mata pencaharian dan lain sebagainya. (3) Menurut proses terjadinya perubahan sosial yang terjadi di Pesisir Payangan termasuk dalam perubahan yang direncanakan karena adanya agen of change yaitu Masyarakat Sadar Wisata (MASSAWI) yang diketuai oleh Bapak Suto Wijaya, KUB Lumba-lumba dan Pengelola wisata Bukit Samboja. 


\section{KESIMPULAN}

Perubahan sosial di Pesisir Payangan terjadi karena adanya penyebab berupa pnemuan tempat wisata baru dan perubahan lingkungan yang dalam prosesnya didorong oleh faktor sikap menghargai masyarakat, orientasi ke masa depan dan stratifikasi sosial masyarakat yang terbuka. Perubahan sosial yang terjadi mendapat hambatan karena faktor SDM masyarakat yang rendah sehingga masyarakat cenderung pasif. Proses perubahan sosial yang terjadi melibatkan berbagai lembaga sebagai saluran perubahan, yang kemudian diikuti oleh penyesuaian yang dilakukan oleh individu dan lembaga masyarakat. Perubahan sosial yang terjadi pada akhirnya memunculkan disorganisasi dan reorganisasi yang bernilai positif dan negatif. Masyarakat yang sudah sadar wisata sebaiknya bisa melanjutkan perubahan yang bernilai positif dan meninggalkan perubahan yang dianggap bernilai negatif.

\section{DAFTAR PUSTAKA}

Devy, H. A. (2017). Pengembangan Obyek Dan Daya Tarik Wisata Alam Sebagai Daerah Tujuan Wisata Di Kabupaten Karanganyar. Jurnal Sosiologi DILEMA, 32(1), 34-44.

Djazifah, N. (2011). Proses Perubahan Sosial di Masyarakat. In Lembaga Penelitian dan Pengabdian Kepada Masyarakat Universitas Negeri Yogyakarta (Vol. 44). https://doi.org/10.1088/1751-8113/44/8/085201

Effendy, M. (2009). Pengelolaan Wilayah Pesisir Secara Terpadu: Solusi Pemanfaatan Ruang, Pemanfaatan Sumberdaya dan Pemanfaatan Kapasitas Asimilasi Wilaah Pesisir Yang Optimal dan Berkelanjutan. Jurnal Kelautan, 2(1), 81-86.

Helmi, A., \& Satria, A. (2012). Strategi Adaptasi Nelayan Terhadap Perubahan Ekologis. Makara Human Behavior Studies in Asia, 16(1), 68. https://doi.org/10.7454/mssh.v16i1.1494

Kementerian Pariwisata. (2016). Kementerian Pariwisata Tahun 2016.

Martono, N. (2014). Metode Penelitian Kuantitatif. Jakarta: Raja Grafindo.

Mulyadi, M. (2015). Perubahan Sosial Masyarakat Agraris ke Masyarakat Industri dalam Pembangunan Masyarakat di Kecamatan Tamalate Kota Makassar. Jurnal Bina Praja, 07(04), 311-321. https:// doi.org/10.21787/jbp.07.2015.311-321

Nurisnaeny, P. S. (2016). Adaptasi Nelayan Kawasan Perbatasan di Desa Sei Pancang, Kecamatan Sebatik Utara, Kabupaten Nunukan, Provinsi Kalimantan Timur. Jurnal Communicate, 1(2), 55-66.

Pratama, E. Y. (2013). Dampak Pengembangan Pariwisata dan Sikap Nelayan di Desa Pangandaran. IPB University.

Sari, D. M. (2015). Partisipasi Masyarakat dalam Mengembangkan Sarana Prasarana Kawasan Desa Wisata Borobudur. MODUL, 15(2), 133-139.

Sztrompka, P. (2015). Sosiologi Perubahan Sosial. In Jakarta (Vol. 3). Jakarta: Prenada. 